\title{
Justice for Mumia Abu-Jamal
}

The movement to free Mumia Abu-Jamal is an international one. Millions

1 of people around the world recognize that Mumia was framed and call for his release. The heart of the movement is based in Philadelphia and is headed by the International Concerned Family and Friends of Mumia AbuJamal. Affiliated with that organization in the US are three main centers of organizing:

International Concerned Family and Friends of Mumia Abu-Jamal PO Box 19709

Philadelphia, PA 19143

(215) 476-8812

www.mumia.org

Free Mumia Abu-Jamal Coalition (NYC)

PO Box 16, College Station

New York, NY 10030

(212) 330-8029 (hotline: leave a message, your call will be returned within 24 hours)

www.freemumia.com

Mobilization to Free Mumia Abu-Jamal

298 Valencia Street

San Francisco, CA 94103

(415) 255-1085

www.freemumia.com

The movement focuses on providing information on Mumia's legal situation, on broader educational events, and on mobilizing people into campaigns and street actions that put pressure on those who control what happens in the court system. We are convinced that the courts will only grant justice to Mumia and other political prisoners when our movement reaches the level and intensity that those in power cannot ignore. We must build such a movement while recognizing the government's constant attacks on us and its many attempts at undermining our work.

While most of us are convinced that Mumia did not kill Officer Faulkner, the crime for which Mumia was convicted and sentenced to death, we welcome all those who believe Mumia did not get a fair trial, regardless of 
whether or not they see Mumia as innocent. We popularize Mumia’s books, his statements, and recorded messages from prison. We frequently focus on Mumia's history in the Black Panther Party as well as his long-time support for the MOVE Organization and the MOVE 9 (nine political prisoners now incarcerated for 27 years) to present the context in which Mumia was framed. We participate in the anti-war movement, the immigrant movement, and many other movements for justice. We bring Mumia`s voice to different struggles to highlight the profound leadership he provides even from Death Row, and to demonstrate the connection between Mumia's struggle and what is happening in our society as a whole: war, repression, destruction of the planet, governmentally sanctioned torture whether at home or abroad, and the general degradation of life. But the issues we address most, those most highlighted by Mumia's case, are the struggle to free all political prisoners, the death penalty, police brutality, and massive U.S. incarceration.

December 9, 2006 will mark the $25^{\text {th }}$ anniversary of Mumia's incarceration. A major activity will take place in Philadelphia on that date. 